\title{
Capital Market and Enterprise Core Competitiveness Interaction Mechanism-Based on the Case of Kangmei Pharmaceutical Co., Ltd
}

\author{
Bo Zou \\ Management School, Jinan University, Guangzhou, China \\ Email: 598043227@qq.com
}

Received 4 March 2015; accepted 12 April 2015; published 17 April 2015

Copyright (C) 2015 by author and Scientific Research Publishing Inc. This work is licensed under the Creative Commons Attribution International License (CC BY). http://creativecommons.org/licenses/by/4.0/

\section{(c) (7) Open Access}

\begin{abstract}
Since the establishment of China's capital market, it has been imperfect. Many listed companies misappropriating the capital market, and some of them want to expand the size through the capital market. It seems that enhance corporate value is impossible, too. However, companies want bigger and stronger cannot do without a strong leverage of the capital market, and enterprises to enhance their value can be counterproductive in the capital markets, improve the efficiency of capital markets. This paper analyzes Kangmei Pharmaceutical Co., Ltd, and the relationship between its financing and value growth in the Chinese capital market, research results exist mutually reinforcing mechanisms between capital market efficiency and core competitiveness of enterprises.
\end{abstract}

Keywords

Capital Markets, Core Competitiveness of Enterprises, Kangmei Pharmaceutical Co., Ltd

\section{Introduction}

The securities market is the main form of capital markets, since 1990 formalized the system construction, there are more than 1400 listed companies, and the market value reached more than three trillion Yuan. In recent years, capital market system is also continuous improvement and innovation, as of December 31, 2007, a total of 1298 Shanghai and Shenzhen listed companies have completed or entered the market capitalization of listed companies accounted for the share reform program should reform the proportion of the total market capitaliza- 
tion of listed companies 98\%, equity division reform basically completed. Moreover, the new "Company Law" and "Securities Act" for capital market development and innovation eliminates many restrictions. At the same time, the relevant agencies have also introduced a new refinancing policy: more convenient way to refinance. However, China's stock market was born and raised in the planned economy and market economy caught in, when it was born from a system of distortion and dislocation on along with it, the system, which makes it function and efficiency have been a strong institutional context suppression, the stock market to optimize the allocation of resources function is twisted into a bear economic, financial restructuring costs and risk transfer tools. Under the government-led institutional change mandatory background Chinese stock market's overall economic efficiency is low: the Shanghai Composite Index appear below 2000 points since 2008, and again fell below 2000 points in 2012. 2000 points still hovering in the stock market shock bottoms inevitably discourage investors; look back to the opening of the GEM, GEI more than four years also ups and downs, in December 2013 there GEI tumbled more than $8 \%$ record the biggest decline, more than 200 stocks hit bottom.

Economic and social financing through the capital market to achieve the optimal allocation of financial resources [1], the provision of financial resources to the market with a minimum transaction costs for those who need money, and secondly, the market demand for funds to use the financial resources to provide the ability to efficiently output to the public [2]. Efficient capital markets should be the allocation of limited financial resources to the benefit of the best business and industry, thus creating the largest output, to achieve social welfare maximization market [3]. And enterprises to create maximum output is to maximize its value, its core that is making the core competitiveness of every business is growing [4].

In the institutional context at this stage, companies want to rely on the capital market financing of funds successfully, and achieve and enhance their core competitiveness goals or improve the efficiency of capital markets by enhancing their core competitiveness of enterprises seem difficult to achieve [5]. However, if the enterprise to develop the right strategy, establish the correct corporate values, relying on bigger and stronger capital market is not impossible, Kangmei Pharmaceutical is a typical example.

\section{The Growth of Kangmei Pharmaceutical in Capital Markets}

Kangmei Pharmaceutical was established in 1997, focusing and strengthening the training of personnel for new drugs and new technology research and application, with strong production scale, good business operating capacity and R \& D capabilities successfully listed on the Shanghai Stock Exchange, has grown into one with Chinese Herbal Medicine, chemical raw materials and preparations for the dominant and pharmaceutical production, research and development and pharmaceuticals, medical devices and marketing in one of the modern large-scale pharmaceutical enterprises, state-level key high-tech enterprises.

\subsection{Successful Listing}

The managers of Kangmei Pharmaceutical fully aware of the important role of the capital market for a company, and only after the market test, to be recognized by the market, is truly outstanding enterprises. Therefore, in order to further integrate resources, The company successfully listed on the Shanghai Stock Exchange in March 2001. This is the first Kangmei Pharmaceutical access to capital markets, as well as its subsequent further financing in the capital markets, leveraging grow premise. It has been able to successfully market, first of all thanks to its good operation status. In recent years, the company has invested a lot of money to introduce advanced production equipment, meanwhile, the company focus and strengthen the training of personnel and production of new drugs and new technology research and application, so that the whole company's technology and management level has leapt to a new level. Moreover, the company synthetic drugs and modern biotechnology drugs, as two of the company's technology development and industrial pillars. In implementing development and implementation of the above, the Institute of Pharmaceutical R \& D work is mainly responsible for the pharmaceutical and chemical synthesis proprietary varieties by located in Jinan University campus "and the Nankang US biomedical research and development base”, mainly responsible for the development of medicine and biology controlled release, sustained release dosage forms of targeted research and development. In addition, the company's financing investment in recent years based on the long-term development. Company over the years has been to raise funds by borrowing from banks required production and operation, all funds borrowed for construction and renovation GMP production workshop, GSP transformation of storage space, the introduction of production equipment, purchase raw materials. These are listed on the Kangmei Pharmaceutical success- 
fully laid a good foundation, so that in 2001 it successfully entered the capital market.

\subsection{Earned First Pot of Gold}

Kangmei issue price of 12.57 Yuan per share initial public offering of 18 million, 226.26 million Yuan of funds financing in 2001. As is shown in Table 1, Kangmei were invested these money to "doxazosinmesylate new APIs and formulations production line", "propiverine hydrochloride New APIs and formulations production line", "paracetamol and pseudoephedrine tablets (Kangmei Lee Type) to expand production scale and new formulations of clarithromycin tablet production line", a total investment of 170 million Yuan, the remaining funds used to supplement the normal course of business liquidity.

From an investment point of view, the direction of the Kangmei focusing on the long-term interests, focusing on its main business investment, improve core competitiveness, paving the way for its take-off performance.

\subsection{Continued Financing in Capital Market}

After listing in 2001, Kangmei’s financing greatly expanded, through a public offering of new shares, short-term financing bonds, convertible bonds, etc., until June 2011, Kangmei total financing of about 0.99 billion Yuan (before financing costs), so huge scale of financing if it is by means of capital market leverage is difficult to accomplish in the short term. After it, Kangmei entering the capital quickly, continuous expansion of the channel, beneficial to further nurture and develop competitive advantage and competitive strength, and constantly improve the industrial chain, foster a competitive advantage. The details of its market financing are shown in Table 2.

Table 1. Kangmei pharmaceutical IPO funds (Units: Thousand Yuan).

\begin{tabular}{|c|c|c|c|c|c|c|}
\hline Project & $\begin{array}{c}\text { Total } \\
\text { Investment }\end{array}$ & $\begin{array}{l}\text { Production Scale } \\
\text { (Thousand) }\end{array}$ & $\begin{array}{c}\text { Sales } \\
\text { Revenue }\end{array}$ & ROI & $\begin{array}{l}\text { Input-Output } \\
\text { Ratio }\end{array}$ & $\begin{array}{l}\text { Dynamic } \\
\text { Payback }\end{array}$ \\
\hline $\begin{array}{l}\text { Doxazosin Mesylate New APIs and } \\
\text { Formulations Production Line }\end{array}$ & 60,000 & 130,000 & 104,000 & $59.55 \%$ & $1: 2.97$ & 2.83 \\
\hline $\begin{array}{l}\text { Propiverine Hydrochloride New APIs } \\
\text { and Formulations Production Line }\end{array}$ & 40,000 & 100,000 & 200,000 & $116.50 \%$ & $1: 1.67$ & 2.08 \\
\hline $\begin{array}{l}\text { Paracetamol and Pseudoephedrine } \\
\text { Tablets (Kangmei Lee Type) to } \\
\text { Expand Production Scale }\end{array}$ & 40,000 & 100,000 & 110,000 & $37.43 \%$ & $1: 7.33$ & 4.17 \\
\hline $\begin{array}{c}\text { New Formulations of Clarithromycin } \\
\text { Tablet Production Line }\end{array}$ & 30,000 & 20,000 & 120,000 & $27.50 \%$ & $1: 8$ & 2.5 \\
\hline
\end{tabular}

Annual data in the table are from the Kangmei pharmaceutical bulletin each year.

Table 2. Kangmei pharmaceutical market financing (Units: Thousand).

\begin{tabular}{|c|c|c|c|c|}
\hline Time & Financing Issues & To Raise the Amount of Financing & Issuance Costs & $\begin{array}{c}\text { The Actual Amount } \\
\text { of the Financing }\end{array}$ \\
\hline 2001-3-19 & IPO & 226,260 & 9790 & 216,470 \\
\hline 2006-8-11 & Issuance of New Shares & 504,000 & 19,000 & 485,000 \\
\hline $2006-10-25$ & Short-Term Bonds & 400,000 & - & 400,000 \\
\hline 2007-9-17 & Issuance of New Shares & $1,047,960$ & 24,730 & $1,023,230$ \\
\hline $2008-5-8$ & Issuance of Bonds with Warrants & 900,000 & 13,000 & 887,000 \\
\hline $2009-5-25$ & Put Warrants Exercisable & 887,460 & - & 887,460 \\
\hline $2010-12-27$ & Allotment & $3,469,890$ & 33,400 & $3,436,490$ \\
\hline $2011-6-23$ & Issuance of Corporate Bonds & $2,500,000$ & - & $2,500,000$ \\
\hline Total & & $9,935,570$ & 99,920 & $9,835,640$ \\
\hline
\end{tabular}




\section{Analysis of the Core Competitiveness of Kangmei Pharmaceutical}

The core competence of Kangmei pharmaceutical improves is due to improve its comprehensive strength, and the improvement of comprehensive national strength, its core lies in its main business promotion, to build the Chinese herbal medicine as the core to improve the supply chain performance, rising in the financial indicators steadily.

\subsection{The Overall Strength Significantly Increased}

As is shown in Figure 1, since Kangmei pharmaceutical listed, its equity, profits, total assets, the market value of all has been the rapid growth. From March 19, 2001 to November 28, 2013, the company's total share capital of 708 million shares rose to 2198.71 million shares, the market value of shares, from 25,790 million Yuan, rose to 42,699 million Yuan, and an increase of 15.56 times the market value. We can see that most of the company project investment funds are from the capital market, and financing has brought the huge development space to Kangmei, its equity, net profit, total assets and shareholder rights and interests have a great increase in the listing. Capital markets provide strong financial support for company operation, to improve the core competence of the corporation. The equity of the company to increase the benefits from two aspects, one is the direct undistributed profit and capital reserves, on the other hand is companies from the capital market allotment of shares. And both of all, need a company with market competitiveness and profitability, therefore, changes in the equity of the company also can indirectly reflect the company's operating condition.

As is shown in Figure 2, by the end of 2012, net profit, total assets, shareholder rights and interests compared to 2000 increased 57.70 times, 76.66 times, and 100.80 times. And as of 2013 September, Kangmei pharmaceutical in 147 with the industry listing corporation, the main business income reached 9400 million Yuan, the industry ranked eighth, and rate of return on net assets ranked twenty-ninth, in front of industry. Kangmei pharmaceutical comprehensive ability rise and enhance its core competitiveness.

\subsection{Analysis of Core Competitiveness}

According to the evaluation index system of the core competitiveness of enterprises [6], we know that the core competitiveness mainly includes the ability of sustainable development and steady growth ability and investment return ability, reliable financial soundness ability, the ability to create value, these are the common characteristics with the core competitiveness of the enterprise is shown. The purpose of financing in the capital market is to enhance the profitability of enterprises, enterprise value growth, a healthy financial returns and the return on investment. We are shown the enterprise core competitiveness evaluation index in Figure 3.

From Figure 4 we can see that, the total return on assets rate, sales growth rate, rate of capital accumulation has been maintained at a high level, and the emergence of high growth in the individual year: the company just listed capital accumulation rate higher than other time points; and Chinese herbal medicine price collapse in 2011 is the main factor affecting Kangmei’s shares fell in 2011 and 2012, Tobin's Q value except in 2011 and 2012 is low, the other time points are also in the twists and turns up status. Overall, since listed, the core competitiveness of Kangmei has improved.

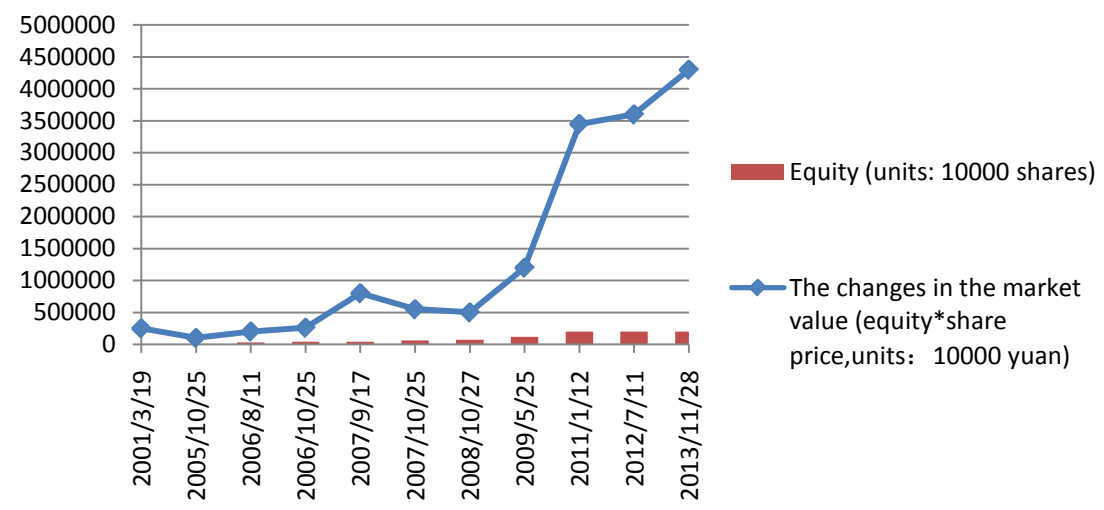

Figure 1. Kangmei’s market value changes from 2001 to 2013. 


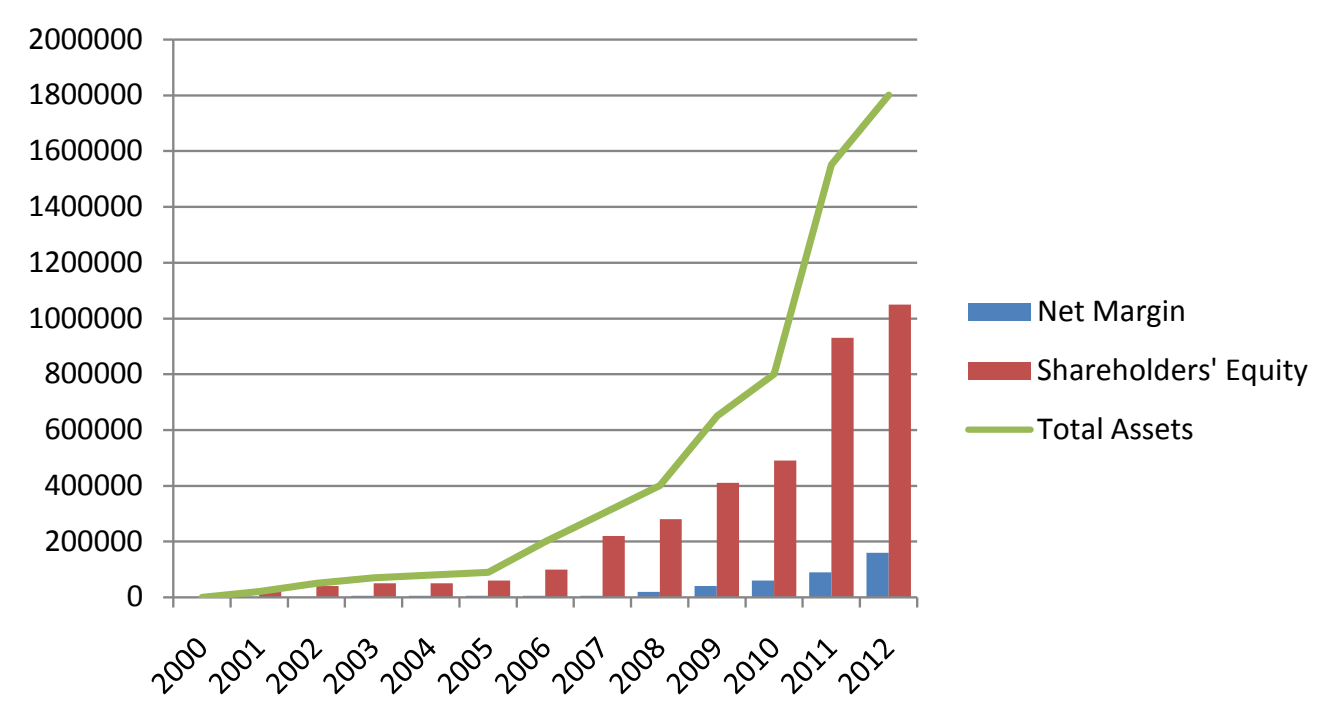

Figure 2. Net profit, total assets, shareholder rights and interests change map (Units: 10,000 Yuan).

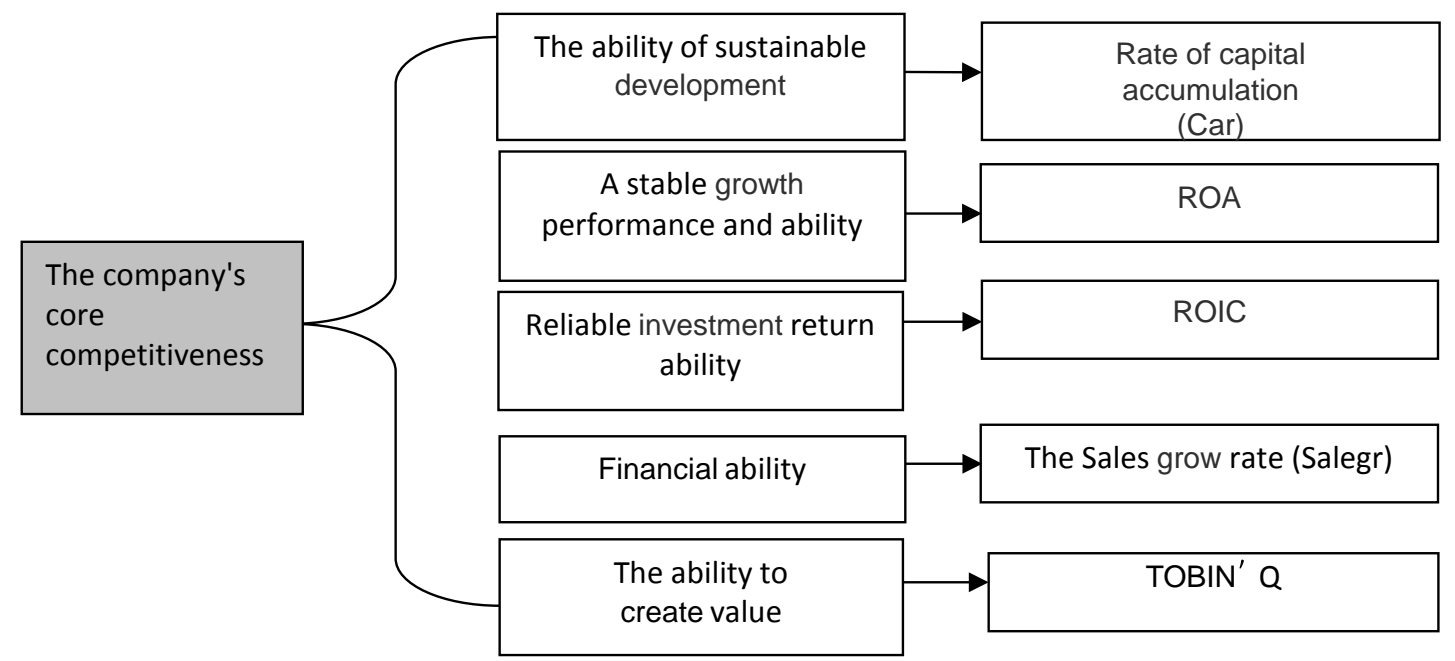

Figure 3. The enterprise core competitiveness evaluation index.

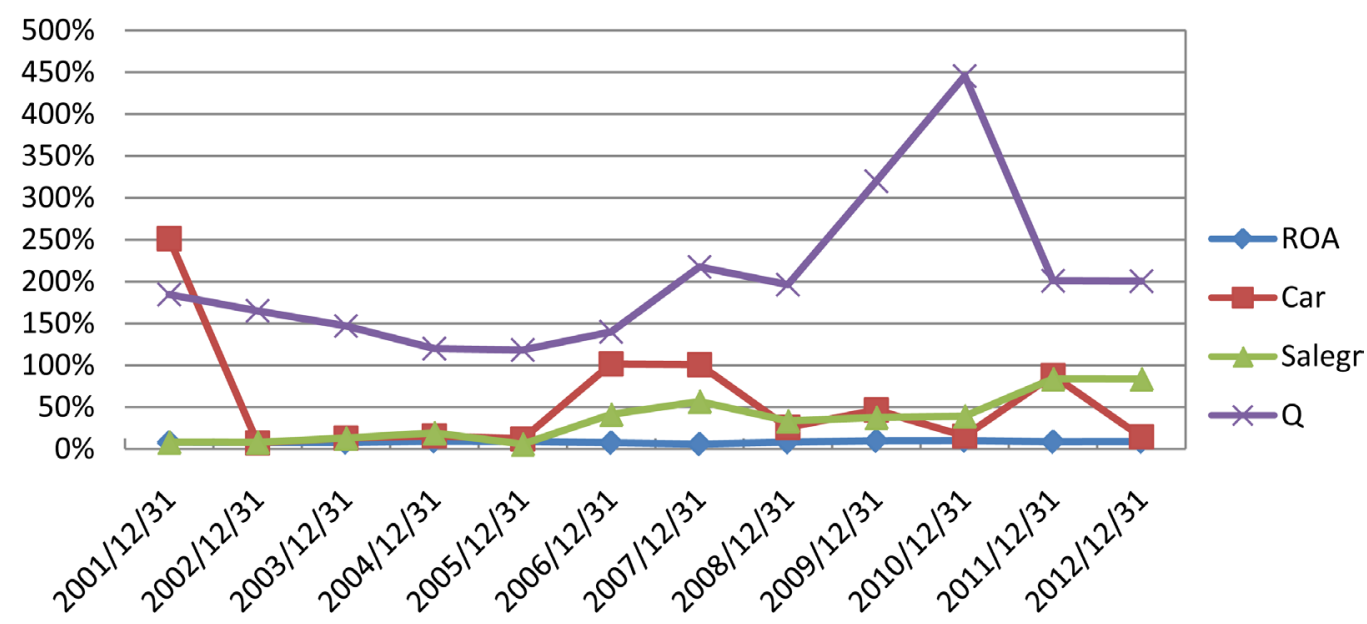

Figure 4. Kangmei's industry core competitiveness index from 2001 to 2012. 


\subsection{The Core Competitiveness of Enterprises and Capital Market Interaction Mechanism Research}

By using the capital market, Kangmei establish a complete industrial chain for the company to expand production scale, improve the strength of the company, enhance the core competitiveness of enterprises, realize the maximization of enterprise value. In the core competitiveness of enterprises on the impact of the capital market, since it has the qualifications listed in 2001, the company to achieve continuous financing through the issuance of new shares, short-term financing bonds, the separation transaction convertible bonds, shares, corporate bonds and other means, the impact of this all cannot do without the company's core competitiveness. Only if the enterprises have strong core competitiveness, can raise more funds in the capital market; enterprises through the capital to support the further development of strong.

We can see that, between the core competitiveness of the capital market and the company does exist a mechanism of interaction, the following is the analysis of the interactive relations between capital market and enterprise core competitiveness.

According to Figure 5 and the whole development process of Kangmei Pharmaceutical Co., Ltd, we can conclude that the interaction mechanism between the capital market and the core competitiveness of enterprises. In order to get the opportunity of obtaining financing, the company has to meet the requirements of listing. As we all know, the enterprise must be a very good performance and compelling strength to go public, and ultimately the source of this strength is the core competitiveness of enterprises. But once the company get listing successfully, it can use the funds that get from the capital market in various areas, such as corporate research and development, expand production, distribution channels, the logistics system, so as to further enhance its strength, and the integration of these tangible or intangible capabilities can make the company have the ability which is difficult for its competitors to imitate , and make the company gain advantage in the continued competition, which formed the core competitiveness of enterprises, and it can further support enterprises to achieve good performance, laid a foundation for the refinancing of enterprises and ultimately achieve a virtuous cycle for enterprise development.

Thus, we found that the capital markets can help to enhance the core competitiveness of enterprises, the better of the core competitiveness of enterprises, the more efficiency of capital markets, that is good for the operation of capital markets. From the case we can see that the rise of the core competitiveness of Kangmei improves the company's profitability effectively, and investors get a good return. That is a prerequisite and necessary condition for the healthy development of capital markets. Therefore, to enhance the core competitiveness of enterprises, in turn, promote the healthy and efficient development of capital markets. There is a positive interaction mechanism between them.

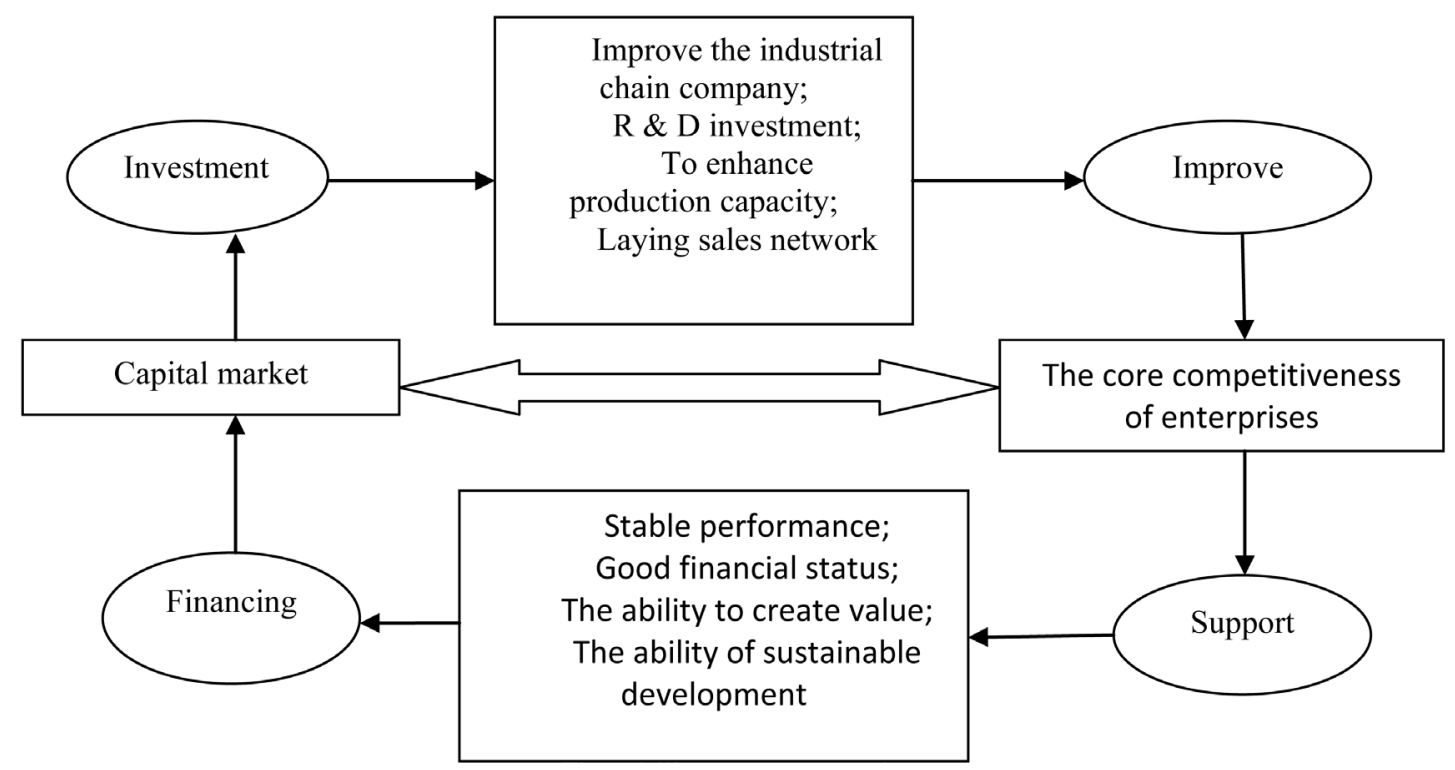

Figure 5. Diagram of the relationship between capital market and enterprise core competitiveness interaction. 


\section{Implications}

Kangmei gets financing from capital market to make the enterprise refreshing, which makes it get into a steady and healthy development road. So, what we can get inspiration from it?

First, the capital market is not just a place to get money. After the listing, companies should have the right values of enhance the company's competitiveness in main area. After obtaining a lot of money, many companies invest diversification and get into the "ST" dilemma. Kangmei gets financing in the capital market and use it to the construction of the industry chain integration, to achieve unified business model, which makes itself a clear competitive advantage in the industry.

Secondly, in order to get bigger and stronger; the capital market leverage is a useful tool. Successful financing in the capital markets to raise a lot of money, so the company has sufficient funds for the construction of the industrial chain integration, acquisition of medicinal plantations, construction logistics transit base, the establishment of Kang Mei Hospital, a series of effective measures to enhance the core competitiveness of enterprises. If large capital needs only rely on bank credit and other indirect methods which often difficult to meet, the financial constraints of funds will also become a bottleneck in the development of enterprises, and by use the financing platform of capital market, enterprises meets the need of funds in the development process and overcomes the obstacles to the development of insufficient funds. Although China's capital market is inefficient, the leverage will help to build achievements of entrepreneurs Albert.

\section{Conclusions}

In this paper, through the analysis of the relationship between Chinese Kangmei pharmaceutical in the capital market financing and the growth of its value, get the interaction mechanism of the capital market and the company core competitiveness, this is the enterprise use of capital market financing and leverage, the successful case of the company rapidly development. Listing corporation can fully make use of the capital market, and constantly improve their competitive ability, and the final victory in the brutal competition in the market.

The innovation of this paper lies in: The research on the core competitiveness, both at home and abroad have achieved fruitful results, but for the study of interaction mechanism between the core competence and the capital market is still relatively small, in order to Kangmei pharmaceutical industry as the research object, through the process of its development in the proper use of the capital market, the promotion enterprise core competitiveness, and achieve the maximization of corporate value, to try to have a more comprehensive understanding of the relationship between the two. Through in-depth interpretation of the case, hoping to find a path for the development of the company's strategy, the enterprises can reduce the possibility of detours, and at the same time, Kangmei pharmaceutical has a certain guiding significance for the further development.

Of course, there are some limitations. Firstly, this paper takes the case of Kangmei pharmaceutical company as the research object, through the effective use of capital market to develop its own competitive analysis, and then draw the interaction mechanism between the capital market and the enterprise's core competitiveness, only for a company to carry on the analysis, for different regions and different sectors, lack of representative the method also need relevant empirical research by scholars further scientific demonstration. Secondly, there are a lot of listing corporation, they listed the intention may be to the development of enterprises, however, under the temptation of money, is not conducive to the development of the company may make some things, such as the transfer of listed financial capital into the private name, or by the means of transfer of benefits, emptied of listing corporation, the as a nurse's role, it is very difficult to realize the interaction mechanism between the capital market and the core competitiveness of enterprises, even if the company to raise funds, may also use some unknown means, does not support this view.

\section{References}

[1] Verrecchia, R.E. (2012) The Role of Capital Market Settings in Disclosure Policy. Accounting Horizons, 26, 385-387. http://dx.doi.org/10.2308/acch-10265

[2] Prahalad, C.K. and Hamel, G. (1990) The Core Competence of the Corporation. Harvard Business Review, 68, 79-91. http://web.ebscohost.com/ehost/detail/detail?sid=534e818a-e604-464a-8714-b4593e897620\%40sessionmgr110\&vid=0 \&hid=128\&bdata=Jmxhbmc9emgtY24mc210ZT1laG9zdC1saXZl\#db=buh\&AN=9006181434

[3] Beaver, W.H. (2002) Perspectives on Recent Capital Market Research. Accounting Review, 77, 453-474. http://dx.doi.org/10.2308/accr.2002.77.2.453 
[4] Leonard-Barton, D. (1992) Core Capabilities and Core Rigidities: A Paradox in Managing New Product Development. Strategic Management Journal, 13, 111-125. http://dx.doi.org/10.1002/smj.4250131009

[5] Liao, Z.R. and Zhang, Z.W. (2006) On the Enterprise's Core Competition Ability and Its Cultivation. Market Modernization, 2, 83-83.

http://www.cnki.net/KCMS/detail/detail.aspx?dbname=cjfd2006\&filename=scxh200602055\&dbcode=CJFD\&urlid=\& yx=\&v=MjMyODFnN3pSckc0SHRmTXJZOUFZWVI4ZVgxTHV4WVM3RGgxVDNxVHJXTTFGckNVUkwrZlkrZ HNGeUhrVzdyTUY=

[6] Huang, W.F. (2009) Study and Application of Measurement Methods of the Core Competence of the Corporation. Science \& Technology Progress and Policy, 2, 77-80.

http://www.cnki.net/KCMS/detail/detail.aspx?dbname=cjfd2010\&filename=kjjb201002022\&dbcode=CJFD\&urlid=\& yx=\&v=MjU1NDdmWStkc0Z5SGxVN3JMRGdmaFRMRzRIOUhNclk5SFpvUjhlWDFMdXhZUzdEaDFUM3FUcld NMUZyQ1VSTCs= 